Pediat. Res. 4: 135-144 (1970)

Adipose tissue

collagen

creatinine

DNA kwashiorkor muscle cell mass protein-calorie malnutrition

\title{
Malnutrition in Infancy: Changes in Muscle and Adipose Tissue Before and After Rehabilitation
}

\author{
Donald B. Gheek ${ }^{[45]}$, Donald E. Hill, Angel Cordano and George G. Graham \\ Division of Growth, Children's Medical and Surgical Center, The Johns Hopkins Hospital, \\ Baltimore, Maryland, and Department of Research, British American Hospital, Lima, Peru
}

\section{Extract}

In nine infants suffering from protein-calorie malnutrition, significantly low values for muscle mass and cell mass which were proportional were observed. These were $1.02 \pm 0.44 \mathrm{~kg}$ and $2,295 \pm 693 \mathrm{pg}$, respectively $(P<0.001)$. The extracellular volume was disproportionally high relative to creatinine excretion before and after rehabilitation. The major loss of muscle mass was due to loss of cell size rather than cell number.

The protein/DNA ratio was $78 \pm 18.7(P<0.001)$ prior to rehabilitation and $109.6 \pm 45.1(P<0.001)$ following rehabilitation. The RNA/DNA ratio was low at $0.96 \pm 0.26(P<0.001)$ prior to rehabilitation while after rehabilitation the value increased to $1.24 \pm 0.14$ but was still less than normal $(P<0.01)$.

The levels of $\mathrm{Mg}$ and $\mathrm{Zn}$ per unit DNA were reduced in muscle prior to rehabilitation. These values were $6.6 \pm 0.7$ and $35.6 \pm 15.8$, respectively $(P<0.001)$.

The significantly reduced protein/DNA and RNA/DNA ratios after rehabilitation suggest either persistent alteration in mechanisms responsible for protein synthesis or a prolonged period necessary for recovery. Muscle cell number was not reduced for body length after rehabilitation. The mean muscle mass of $1.67 \pm 0.64 \mathrm{~kg}$ was not significantly different from the normal for body length after rehabilitation.

The concentrations of water $(39.96 \pm 16.99)$ and collagen $(3.86 \pm 2.24)$ in adipose tissue were elevated $(P<0.01)$, while that of fat $(50.36 \pm 21.87)$ was low prior to rehabilitation. The noncollagen protein was constant per gram of tissue in marasmus and following rehabilitation.

\section{Speculation}

Because insulin is intimately related to protein synthesis and the attainment of normal cytoplasmic growth, the persistently poor secretion of insulin during rehabilitation from malnutrition may be responsible for inadequate cytoplasmic growth.

Insulin administered judiciously during the recovery phase may accelerate recovery and insure a return to normal. 
Introduction

Protein-calorie malnutrition is a phenomenon of major importance to world health and to those interested in the study of growth and development. It has been known for some years [35] that the relative loss of muscle mass exceeds that of body weight in marasmus. Fat mass is also grossly reduced and during rehabilitation 'muscle bulk' doubles and fat mass may increase as much as threefold. In marasmus, excess hydration is expected [1], particularly of the extracellular phase $[5,6,23]$. This is associated with relative increments of collagen [20,31]. Restoration of the cellular phase or of metabolically active protoplasm is of great importance $[15,29]$ since expansion of the extracellular phase may persist after treatment [23]. Limited information exists regarding the changes in human tissues before and after treatment but it has been estimated that approximately one-half of the muscle protein mass is lost in marasmus [35, 38].

A review of all types of growth retardation has drawn attention to the need to inspect normal and abnormal human growth in terms of the size and number of cells [8].

Animal experimentation has shown that proteincalorie restriction in the pre- and postweaning period leads to a reduction in the number of cells in major tissues $[14,26,39]$. If the postweanling rat is restricted in calories but has a marginal or normal protein intake there is some reduction in muscle cell number and an increase in muscle cell size in comparison with age mates $[14,18]$. Rats subjected to a $6 \%$ protein intake in the postweaning period and with some voluntary restriction of calories, however, demonstrate reduction in the protein/DNA ratio of muscle $[22,26]$ and complete cessation of cell number increase. Thus, in rats, it is possible to define a distinct difference in cell growth between a situation with protein-calorie restriction and one with calorie restriction alone.

The purpose of the present paper is to describe the chemical composition of muscle in male Peruvian infants admitted to the hospital with protein-calorie malnutrition. They were studied before treatment was initiated and after receiving an adequate diet for 4-9 months. In addition, information is presented on the composition of adipose tissue obtained by biopsy before and after rehabilitation. A previous paper concerning the same infants [16] contains information about intracellular and extracellular water, creatinine and hydroxyproline excretion, serum growth hormone, and insulin concentrations before and after arginine infusion. Informed consent was obtained for all subjects in this study [42].
Clinical Material

Nine, male Peruvian infants with protein-calorie malnutrition were investigated during the first month of admission to the British American Hospital in Lima, Peru. All exhibited severe malnutrition with loss of subcutaneous fat and muscle wasting.

The age range of the infants, $M 1-M 9$, at the initial investigation was $0.43-2.53$ years; five were under 1 year of age. The second study occurred 4-9 months later when the ages ranged from $0.81-2.83$ years; at that time five of the infants were from 1 to 2 years of age. At the time of the initial study all infants had severe deficits in height and even greater deficits in weight relative to the Boston Growth Chart. Patients $M 1, M 5$, and $M 6$ showed definite signs of kwashiorkor on admission suggesting a relatively greater depletion of protein than of calories. The marasmus of the re maining infants suggested a more balanced reduction in protein and calories. At the time of the first investigation the patients received a diluted Similac formula; during the subsequent study period they were fed a creatinine-free diet composed of cane sugar, cottonseed oil, and casein together with minerals and vitamins. Further details of this diet are given elsewhere [16].

\section{Muscle \\ Methods}

Methods for the determination of DNA, RNA, tissue $\mathrm{Gl}, \mathrm{Mg}, \mathrm{Zn}$, protein, and collagen have all been described $[7,18]$. The sample of muscle and $1 \mathrm{~g}$ of adipose tissue were taken from the gluteal region of each patient using a method described previously [37].

Individual cell mass of muscle $(\mathrm{cm})$ is best defined by the following equation [7]:

$\mathrm{cm}, \mathrm{pg}=$ fat-free fresh muscle/g-chloride space $/ \mathrm{g} \div$ nuclear (cell) number/g

Cell size is also reflected by the protein/DNA ratio. These indices of cell size are based on the assumption that no cells are present in the extracellular phase and that connective tissue cells are minimal.

Creatinine excretion and serum creatinine level were measured by the method of HARE [21]. It was considered that with a low creatinine diet $1 \mathrm{~g}$ of creatinine excreted per $24 \mathrm{~h}$ for a normal child represents $20 \mathrm{~kg}$ of muscle mass [11, 17]. Consideration of the validity for using this calculation in malnutrition will be given.

The amount of DNA per nucleus $(6.2 \mathrm{pg})$ was considered to be constant [7]. Number of nuclei per gram of muscle can be calculated in the whole musculature of the normal child as the number of grams of muscle mass $\times$ number of nuclei per gram, provided the muscle sample is representative of the musculature as a whole. This may or may not be the case in marasmus. 
The data from the muscle of the malnourished infants before and after rehabilitation were compared with data published elsewhere for normal male infants [7] and with unpublished data covering the age period under study. Mean values are recorded in the tables. The individual values for muscle before and after rehabilitation were compared by paired analysis using the $t$ test [25]. Comparison with normal data was done using group mean values.

\section{Adipose Tissue}

After surgical removal of approximately $1 \mathrm{~g}$ of adipose tissue, the sample was weighed in a tared vessel; it was dried to constant weight at $100^{\circ}$ and the fat was extracted with petroleum ether until constant weight was obtained. The residue was designated fat-free dry solid. This dry solid was then analyzed for total nitrogen and hydroxyproline [13]. The total protein and the fraction of collagen also were calculated. All results were expressed as grams per $100 \mathrm{~g}$ of fresh adipose tissue. The results of analysis of adipose tissue from the Peruvian infants, before and after rehabilitation, have been compared with analyses of subcutaneous fat obtained from eight normal male infants.

\section{Results}

A companion paper [16] has demonstrated that during rehabilitation all patients had satisfactory linear growth and all except one (MG) gained in body weight. All except patients $M 2$ and $M 6$ had exceeded expected weight for height and presumably had almost recovered from protein-calorie malnutrition. Patient M6 consumed less food during the last 3 months of rehabilitation. All patients with an initial age greater than 0.9 years (except $M 6$ ) had a significant increase in their metabolically active tissues (as reflected by intracellular water) during rehabilitation $(M 1, M 3, M 5$, and $M 7)$. Those below 0.9 years ( $M 2, M 4, M 8$, and M9) did not show such a remarkable increase in intracellular mass [16], but rather appeared to show greater increments in extracellular volume and body fat.

Data concerning muscle analyses before and after rehabilitation are contained in table I. The concentration of protein in muscle was reduced before and after rehabilitation compared with normal infants. Evaluation of muscle cell size by inspection of the protein/DNA ratio versus body length (fig. 1) revealed that all patients had a gross reduction compared with normal infants. With rehabilitation there was an increase in muscle cell size toward normal in all instances except one (MG). The change was only remarkable in the case of patients $M 2$ and $M 5$, but the older patients ( $M 1, M 5$, and $M 7$ ) were closer to the normal after rehabilitation. In table I, the individual cell mass is recorded in picograms and the changes in the individual cell mass reflect the changes found in the protein/DNA ratio.

The concentration of RNA in the fresh fat-free muscle of malnourished infants was higher than normal, while after rehabilitation normal values were found. The RNA per unit DNA (mg/mg) in the muscle tissue for 15 normal infants was found to be $1.63 \pm 0.49$. Malnourished infants had a mean value of $0.96 \pm 0.26$ $(P<0.001)$ and although the value increased to $1.24 \pm$ $0.14(P<0.01)$ after rehabilitation it was still less than normal $(P<0.01)$. Three of the four younger patients (M4, M8, and M9) had the lowest initial values.

No analyses were made for collagen and fat in the muscle samples from patients $M 1, M 4, M 8$, and $M 9$ prior to rehabilitation. The values for collagen in muscle did not differ from normal, but a trend toward a high value was found in the initial study in patient.s $M 2$ and M5. The fat content of muscle was increased both before and after rehabilitation when comparison was made with normal children.

Data concerning muscle $\mathrm{Mg}$ and $\mathrm{Zn}$ are recorded in table II. The values for $\mathrm{Mg}$ were reduced before and

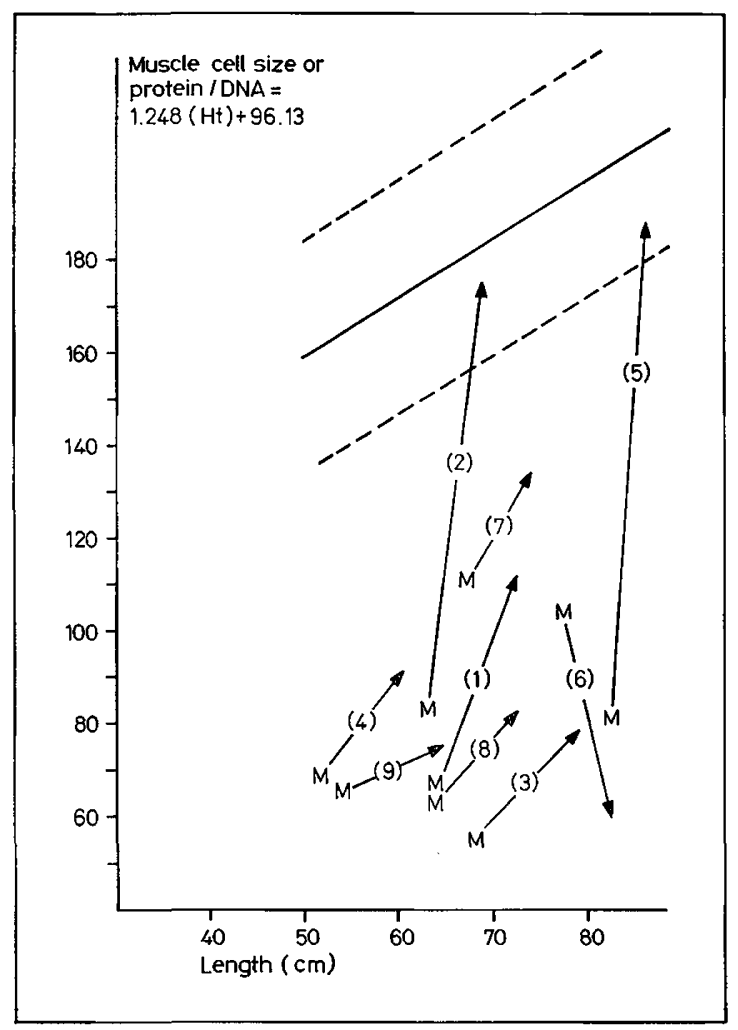

Fig. 1. The protein/DNA ratio in muscle of the malnourished infants is shown against body length. In all instances there was a gross reduction in cell size. After partial rehabilitation all infants except one showed increments in cell size and to a variable degree. 
after rehabilitation irrespective of whether the data were considered on the basis of fresh fat-free tissue, or per unit DNA. Similarly, the values for $\mathrm{Zn}$ were reduced in muscle at the outset of the study. After rehabilitation, however, the values returned towards normal.
Table III contains data concerning the estimated muscle mass (from creatinine excretion) and the creatinine clearance ( $\mathrm{Crc}$ ). It has been shown [16] that creatinine excretion was reduced relative to length in these patients, and that with rehabilitation the values

Table I. Muscle composition

\begin{tabular}{|c|c|c|c|c|c|c|c|c|}
\hline & & $\begin{array}{l}\text { Protein, } \\
\text { mg/g } \\
\text { FFFM }^{1}\end{array}$ & $\frac{\text { Protein }}{\text { DNA }}$ & $\begin{array}{c}\text { Individual } \\
\text { cell mass, } \\
\text { pg }\end{array}$ & $\begin{array}{c}\text { RNA, } \\
\mathrm{mg} / \mathrm{g} \\
\text { FFFM }\end{array}$ & $\frac{\text { RNA }}{\text { DNA }}$ & $\begin{array}{c}\text { Collagen, } \\
\mathrm{mg} / \mathrm{g} \\
\text { FFDM }^{2}\end{array}$ & $\begin{array}{c}\text { Fat, } \\
\mathrm{g} / 100 \mathrm{~g} \\
\mathrm{FM}^{3}\end{array}$ \\
\hline \multirow[t]{3}{*}{ Control } & Mean & 192 & 183.8 & 4,253 & 1.68 & 1.63 & 54.0 & 0.67 \\
\hline & SD & 7.5 & 35.0 & 712 & 0.37 & 0.49 & 20.9 & 0.37 \\
\hline & $\mathbf{N}$ & 14 & 15 & 17 & 15 & 15 & 24 & 18 \\
\hline
\end{tabular}

Malnourished

a) Before rehabilitation

$\begin{array}{llccccccc}M 1 & 151 & 67.3 & - & 1.50 & 0.67 & - & - \\ M 2 & & 149 & 83.5 & 2,038 & 1.78 & 1.00 & 125 & 2.22 \\ M 3 & & 134 & 55.8 & 1,434 & 2.78 & 1.16 & 36 & 7.26 \\ M 4 & & 179 & 69.0 & - & 1.94 & 0.75 & - & - \\ M 5 & & 161 & 81.6 & 2,023 & 2.51 & 1.27 & 119 & 5.26 \\ M 6 & & 177 & 103.9 & 2,798 & 1.93 & 1.13 & 58 & 12.55 \\ M 7 & & 151 & 110.9 & 3,185 & 1.75 & 1.28 & 90 & 6.22 \\ M 8 & & 139 & 64.6 & - & 1.44 & 0.67 & - & - \\ M 9 & & 160 & 65.8 & - & 1.76 & 0.72 & - & - \\ & \text { Mean } & 155 & 78.0 & 2,295 & 1.93 & 0.96 & 85.0 & 6.70 \\ & \text { SD } & 15 & 18.7 & 693 & 0.44 & 0.26 & 34.8 & 3.7 \\ P_{1}^{4} & \mathrm{~N} & 9 & 9 & 5 & 9 & 9 & 5 & 5 \\ & & <0.001 & <0.001 & <0.001 & <0.005 & <0.001 & \mathrm{~ns}^{5} & <0.005\end{array}$

b) After rehabilitation

\begin{tabular}{|c|c|c|c|c|c|c|c|c|}
\hline$M 1$ & & 170 & 111.6 & 2,683 & 1.64 & 1.07 & 94 & - \\
\hline M2 & & 166 & 174.0 & 4,667 & 1.37 & 1.44 & 32 & 3.88 \\
\hline M3 & & 134 & 78.1 & 3,010 & 2.32 & 1.35 & 54 & 3.15 \\
\hline M4 & & 124 & 90.5 & 3,336 & 1.50 & 1.10 & 86 & - \\
\hline M5 & & 215 & 184.7 & 3,864 & 1.63 & 1.40 & 49 & 3.01 \\
\hline M6 & & 119 & 60.3 & 2,035 & 1.63 & 1.21 & 72 & 3.38 \\
\hline$M 7$ & & 176 & 133.1 & 3,385 & 1.37 & 1.04 & 46 & 6.18 \\
\hline$M 8$ & & 141 & 82.2 & 3,057 & 2.16 & 1.26 & 41 & 2.41 \\
\hline M9 & & 138 & 71.8 & 2,327 & 2.48 & 1.29 & 66 & 3.32 \\
\hline & Mean & 153 & 109.6 & 3,151 & 1.79 & 1.24 & 60.0 & 3.62 \\
\hline & SD & 30 & 45.1 & 796 & 0.42 & 0.14 & 19.8 & 1.2 \\
\hline & $\mathbf{N}$ & 9 & 9 & 9 & 9 & 9 & 9 & 7 \\
\hline$P_{2}^{4}$ & & $<0.001$ & $<0.001$ & $<0.005$ & ns & $<0.01$ & ns & $<0.001$ \\
\hline
\end{tabular}

1 FFFM = fat-free fresh muscle.

2 FFDM $=$ fat-free dry muscle.

${ }^{3} \mathrm{FM}=$ fresh muscle.

${ }^{4} P_{1}=$ Control versus $a . \quad P_{2}=$ Control versus $b$.

${ }^{5} \mathrm{~ns}=$ not significant. 
Table II. Magnesium and zinc in muscle

\begin{tabular}{|c|c|c|c|c|c|}
\hline \multirow[t]{2}{*}{ Subjects } & & \multicolumn{2}{|c|}{ Zinc } & \multicolumn{2}{|c|}{ Magnesium } \\
\hline & & $\begin{array}{c}\mu \mathrm{g} / \mathrm{g} \\
\text { FFFM }^{1}\end{array}$ & $\begin{array}{l}\text { per mg } \\
\text { DNA }\end{array}$ & $\begin{array}{c}\mathrm{mEq} / 100 \mathrm{~g} \\
\text { FFFM }^{1}\end{array}$ & $\begin{array}{l}\mu \mathrm{Eq} / \mathrm{mg} \\
\text { DNA }\end{array}$ \\
\hline Normal, $0.13-3.75$ yr & $\begin{array}{l}\text { Mean } \\
\text { SD } \\
\mathrm{N}\end{array}$ & $\begin{array}{c}107.7 \\
28.8 \\
13\end{array}$ & $\begin{array}{l}87.4 \\
23.2 \\
13\end{array}$ & $\begin{array}{l}1.56 \\
0.16 \\
21\end{array}$ & $\begin{array}{r}13.9 \\
3.6 \\
21\end{array}$ \\
\hline Malnourished before rehabilitation & $\begin{array}{l}\text { Mean } \\
\text { SD } \\
\mathrm{N} \\
P^{2}\end{array}$ & $\begin{array}{c}64.0 \\
30.9 \\
5 \\
<0.02\end{array}$ & $\begin{array}{c}35.6 \\
15.8 \\
5 \\
<0.001\end{array}$ & $\begin{aligned} & 1.13 \\
& 0.22 \\
& 4 \\
&<0.001\end{aligned}$ & $\begin{aligned} & 6.6 \\
& 0.7 \\
& 4 \\
&< \\
&<.001\end{aligned}$ \\
\hline Malnourished after rehabilitation & $\begin{array}{l}\text { Mean } \\
\text { SD } \\
\mathrm{N} \\
P^{2} \\
\end{array}$ & $\begin{array}{c}80.9 \\
44.7 \\
4 \\
\mathrm{~ns}^{3} \\
\end{array}$ & $\begin{array}{c}59.8 \\
29.5 \\
4 \\
\text { ns } \\
\end{array}$ & $\begin{array}{l}1.22 \\
0.33 \\
7 \\
<0.02 \\
\end{array}$ & $\begin{aligned} & 7.8 \\
& 2.0 \\
& 7 \\
&< \\
&< 0.001 \\
&\end{aligned}$ \\
\hline
\end{tabular}

1 FFFM = fat-free fresh muscle.

2 Probability value versus normal.

${ }^{3} \mathrm{~ns}=$ not significant.

Table III. Muscle mass and cell number

\begin{tabular}{|c|c|c|c|c|c|c|c|}
\hline Patient & $\begin{array}{c}\text { Age, } \\
\text { yr }\end{array}$ & $\begin{array}{l}\text { Height, } \\
\text { cm }\end{array}$ & $\begin{array}{c}\text { Body wt, } \\
\text { kg }\end{array}$ & $\begin{array}{c}\mathrm{MM}^{1}, \\
\mathrm{~kg}\end{array}$ & $\begin{array}{c}\mathrm{CNG}^{2} \\
\times 10^{9}\end{array}$ & $\begin{array}{c}\mathrm{ICW}^{3}, \\
\text { liter }\end{array}$ & $\begin{array}{c}\mathrm{Crc}^{4} \\
\mathrm{ml} / \mathrm{min} \\
1.73 \mathrm{~m}^{2}\end{array}$ \\
\hline \multicolumn{8}{|c|}{ Before rehabilitation } \\
\hline$M 1$ & 1.10 & 63.7 & 4.94 & 0.66 & 0.36 & 1.75 & 63.0 \\
\hline$M 2$ & 0.65 & 62.9 & 4.30 & 0.62 & 0.29 & 2.06 & 21.1 \\
\hline M3 & 1.37 & 68.3 & 5.11 & 1.00 & 0.39 & 2.05 & - \\
\hline$M 4$ & 0.43 & 51.7 & 3.25 & 0.64 & 0.42 & 1.59 & 52.9 \\
\hline M5 & 2.53 & 82.3 & 9.33 & 1.70 & 0.32 & 3.09 & 81.6 \\
\hline$M 6$ & 1.74 & 77.6 & 8.43 & 1.72 & 0.28 & 2.87 & 46.6 \\
\hline$M 7$ & 0.96 & 66.8 & 5.95 & 1.20 & 0.22 & 1.95 & 52.5 \\
\hline$M 8$ & 0.86 & 64.2 & 5.40 & 1.06 & 0.35 & 2.23 & 27.7 \\
\hline$M 9$ & 0.44 & 53.9 & 3.41 & 0.62 & 0.39 & 1.45 & 33.4 \\
\hline \multicolumn{8}{|c|}{ After rehabilitation } \\
\hline$M 1$ & 1.46 & 72.7 & 9.00 & 1.42 & 0.25 & 3.27 & - \\
\hline$M 2$ & 1.13 & 69.0 & 7.68 & 1.32 & 0.15 & 2.46 & 37.4 \\
\hline$M 3$ & 2.10 & 79.3 & 11.31 & 2.36 & 0.28 & 3.91 & 57.0 \\
\hline$M 4$ & 0.87 & 60.6 & 7.01 & 1.14 & 0.21 & 1.86 & 47.9 \\
\hline$M 5$ & 2.83 & 86.7 & 12.45 & 2.96 & 0.19 & 4.10 & 89.0 \\
\hline$M 6$ & 2.28 & 82.6 & 10.03 & 1.98 & 0.32 & 3.30 & 53.4 \\
\hline$M 7$ & 1.33 & 73.8 & 9.63 & 1.48 & 0.21 & 3.10 & 39.0 \\
\hline$M 8$ & 1.40 & 72.55 & 9.74 & 1.34 & 0.28 & 2.69 & 44.1 \\
\hline M9 & 0.81 & 64.3 & 7.69 & 1.02 & 0.31 & 2.07 & 52.8 \\
\hline
\end{tabular}

${ }^{1} \mathrm{MM}=$ muscle mass.

${ }^{2} \mathrm{CNG}=$ cell number per gram of muscle.

${ }^{3} \mathrm{ICW}=$ intracellular water.

${ }^{4} \mathrm{Crc}=$ creatinine clearance. 
moved toward the expected normal. It can be pointed out that if the relation between intracellular water (ICW, liters) (a direct index of intracellular mass) is plotted against creatinine excretion before and after rehabilitation, a linear relation is defined.

$$
\text { Creatinine/day, } \begin{aligned}
\mathrm{mg} & =36.60(\mathrm{ICW})-26.34 \\
\mathrm{sE} & =11.09 \mathrm{mg} \\
r & =0.93
\end{aligned}
$$

This linear relation does not depart from the normal relation calculated for 20 normal male infants of the same age range:

$$
\begin{aligned}
\text { Creatinine/day, } \mathrm{mg} & =29.01(\mathrm{ICW})-7.41 \\
\mathrm{SE} & =13.61 \mathrm{mg} \\
r & =0.92
\end{aligned}
$$

By analysis of covariance, the relations do not differ. If extracellular volume is used instead of intracellular water, however, the relations are again linear with a similar slope, but malnourished children have a greater extracellular mass relative to creatinine excretion $(P<0.01)$. It would appear reasonable to believe that with restricted nutrition the relation of the muscle mass to total cell mass is the same in malnourished infants as in normal infants, and therefore, creatinine excretion still reflects muscle mass.

It can be argued that creatinine excretion may be reduced in malnutrition, due, for example, to incomplete creatinine excretion. Four normal Peruvian infants were found to have a mean creatinine concentration in serum of $0.58 \pm 0.1 \mathrm{mg} / 100 \mathrm{ml}$. Three patients, all less than 0.9 years ( $M 2, M 8$, and $M 9$ ) had serum creatinine values at the time of the initial study that exceeded the normal range $(1.33,0.71$, and $1.05 \mathrm{mg} /$ $100 \mathrm{ml}$, respectively). If calculations were made of the amount of excess creatinine distributed over the total body water, it can be shown that significant amounts were retained by the three younger patients, $M 2, M 8$, and M9. Similarly, if the creatinine clearance of the four normal Peruvian infants $\left(42-82 \mathrm{ml} / \mathrm{min} / 1.73 \mathrm{~m}^{2}\right)$ are compared with creatinine clearance values of the experimental group, patients $M 2, M 8$, and $M 9$ had low creatinine clearance values per unit of surface area. However, expected amounts of creatinine should be excreted per day since no overt renal failure was present. Renal failure would cause marked creatinine retention and creatinine excretion would no longer hold a normal relation to total cell mass.

Table III also contains information on cell number per gram of muscle. The values at the time of the initial study were considerably greater than those for normal infants of the same length. The mean value for 27 normal children of similar length was $0.18 \times 10^{9} \pm 0.03$ $\times 10^{9}$, while the mean value for the malnourished infants was $0.33 \times 10^{9} \pm 0.05 \times 10^{9}(t=10.9 ; P<0.001)$.
If the values for 'predicted muscle mass' are reasonably representative at the time of the initial study, then the mean value equaled $1.02 \pm 0.44 \mathrm{~kg}$, while 21 normal infants of similar length had a value of $1.60 \pm 0.62 \mathrm{~kg}$. A greater deficit for muscle mass would exist if age were the base line. It would appear that muscle mass is reduced for length and the major loss is due to reduction of cell size. Reductions in the number of nuclei of muscle would not be great.

Following rehabilitation, the mean muscle mass $1.67 \pm 0.64 \mathrm{~kg}$ was not significantly different from the normal value (for body length). The number of cells per gram of muscle decreased to $0.24 \times 10^{9} \pm 0.07 \times 10^{9}$ $(P<0.01)$, a value that was still greater than normal for length. It would appear that total number of nuclei in the musculature was not reduced for body length after rehabilitation. These patients, however, had not reached expected length for age and some reduction of cell number for age could have been present.

Table IV contains information on the analyses of adipose tissue. Initially, the percentage of water, protein, and collagen in fresh tissue was higher while the percentage of fat was less than that found after rehabilitation. This was particularly true for patients $M 2, M 3$, and $M 4$; however, the initial findings were similar to findings present in normal adipose tissue, except that more water $(P<0.05)$ and less fat existed in malnutrition. The latter finding was not significant, but patients $M 1, M 2, M 3, M 4$, and $M 9$ had values for fat lower than any in the control group.

\section{Discussion}

This study describes the biochemical changes found in muscle and adipose tissue of malnourished infants before and after rehabilitation. Attention must be drawn to the fact that all normal data were obtained from white infants. Since weight was normal for height in seven of nine subjects after rehabilitation, it might appear that recovery was satisfactory in most instances. It cannot be assumed that a normal situation had been reached, however, since biochemical evidence indicated departures from normal [16].

The RNA/DNA ratio was significantly reduced in muscle but returned toward normal with rehabilitation. None of the patients reached the expected value of 1.6. Since RNA is intimately related to protein synthesis $[10,40]$, it was not unexpected that a major finding in this study was the diminution of cell size in muscle during malnutrition, which in most instances failed to achieve normal levels following rehabilitation. The younger patients appeared to be most affected, and as found previously [16], following rehabilitation these patients showed less of an increase of their intracellular mass than the older patients. 
Table IV. Composition of fresh adipose tissue

\begin{tabular}{|c|c|c|c|c|c|c|c|}
\hline Patient & Age, yr & $\mathrm{H}_{2} \mathrm{O}, \%$ & Fat, $\%$ & FFDS $^{1}, \%$ & Protein, \% & Gollagen, \% & $\mathrm{NGP}^{2}, \%$ \\
\hline \multicolumn{8}{|c|}{ Malnourished children } \\
\hline \multicolumn{8}{|c|}{ a) Prior to treatment, age range $0.42-2.54 \mathrm{yr}$} \\
\hline$M 1$ & 1.10 & 44.67 & 49.41 & 5.91 & 4.80 & 1.85 & 2.95 \\
\hline$M 2$ & 0.65 & 66.56 & 10.52 & 22.91 & 12.05 & 9.10 & 2.95 \\
\hline$M 3$ & 1.37 & 62.36 & 24.35 & 13.29 & 12.04 & 5.36 & 6.68 \\
\hline$M 4$ & 0.43 & 45.47 & 43.17 & 11.36 & 10.99 & 4.11 & 6.87 \\
\hline$M 5$ & 2.53 & 39.46 & 54.75 & 5.79 & 5.60 & 2.63 & 2.97 \\
\hline$M 6$ & 1.74 & 18.96 & 75.70 & 5.34 & 4.71 & 2.50 & 2.22 \\
\hline$M 7$ & 0.96 & 25.42 & 68.09 & 6.49 & 5.01 & 3.51 & 1.50 \\
\hline$M 8$ & 0.86 & 20.44 & 73.15 & 6.41 & 5.44 & 2.23 & 3.24 \\
\hline$M 9$ & 0.44 & 36.26 & 54.10 & 9.64 & 8.77 & 3.44 & 5.33 \\
\hline Mean & & 39.96 & 50.36 & 9.68 & 7.71 & 3.86 & 3.86 \\
\hline SD & & 16.99 & 21.87 & 5.70 & 3.24 & 2.24 & 1.95 \\
\hline $\mathrm{N}$ & & 9 & 9 & 9 & 9 & 9 & 9 \\
\hline \multicolumn{8}{|c|}{ b) After treatment, age range $0.79-2.88 \mathrm{yr}$} \\
\hline$M 1$ & 1.46 & 12.96 & 82.04 & 5.00 & 3.06 & 1.16 & 1.91 \\
\hline$M 2$ & 1.13 & 20.19 & 70.28 & 9.53 & 3.68 & 1.62 & 2.06 \\
\hline$M 3$ & 2.10 & 17.59 & 76.05 & 6.35 & 3.47 & 0.60 & 2.87 \\
\hline$M 4$ & 0.87 & 14.51 & 80.19 & 5.30 & 2.36 & 0.58 & 1.78 \\
\hline$M 5$ & 2.83 & 31.72 & 59.70 & 8.58 & 7.29 & 3.06 & 4.23 \\
\hline M6 & 2.28 & 20.71 & 71.90 & 8.20 & 6.12 & 1.33 & 4.78 \\
\hline$M 7$ & 1.33 & 13.15 & 81.14 & 5.71 & 3.03 & 0.43 & 2.60 \\
\hline$M 8$ & 1.40 & 16.77 & 77.39 & 5.84 & 5.21 & 2.36 & 2.85 \\
\hline$M 9$ & 0.81 & 13.67 & 81.59 & 4.74 & 4.00 & 2.26 & 1.74 \\
\hline Mean & & 17.92 & 75.50 & 6.58 & 4.25 & 1.49 & 2.76 \\
\hline $\mathrm{SD}$ & & 5.94 & 7.36 & 1.74 & 1.63 & 0.92 & 1.09 \\
\hline $\mathrm{N}$ & & 9 & 9 & 9 & 9 & 9 & 9 \\
\hline \multicolumn{8}{|c|}{ c) Control children, age range $0.16-2.35 \mathrm{yr}$} \\
\hline $\mathcal{N} 51$ & 0.92 & 8.40 & 87.32 & 4.28 & 3.92 & 1.91 & 2.01 \\
\hline $\mathcal{N} 55$ & 1.83 & 15.31 & 78.59 & 6.10 & 5.56 & 3.22 & 2.34 \\
\hline $\mathcal{N} 56$ & 2.08 & 35.01 & 55.15 & 9.84 & 8.49 & 6.06 & 2.42 \\
\hline $\mathcal{N} 57$ & 1.66 & 24.79 & 68.69 & 6.52 & 6.20 & 2.85 & 3.35 \\
\hline $\mathcal{N} 59$ & 0.16 & 28.58 & 63.43 & 7.99 & 6.01 & 4.12 & 1.90 \\
\hline C1 & 1.72 & 40.48 & 47.26 & 12.26 & 10.48 & 3.52 & 6.96 \\
\hline$C 2$ & 2.35 & 30.31 & 62.02 & 7.67 & 6.80 & 2.78 & 4.02 \\
\hline$C 5$ & 0.29 & 17.02 & 73.82 & 9.15 & 7.87 & 2.44 & 5.43 \\
\hline Mean & & 24.99 & 67.04 & 7.98 & 6.92 & 3.36 & 3.55 \\
\hline $\mathrm{SD}$ & & 10.78 & 12.90 & 2.47 & 2.01 & 1.28 & 1.82 \\
\hline $\mathbf{N}$ & & 8 & 8 & 8 & 8 & 8 & 8 \\
\hline \multirow{3}{*}{\multicolumn{2}{|c|}{$\begin{array}{r}\text { Paired } P \text { when } a \text { versus } b \\
P \text { when } a \text { versus } c \\
P \text { when } b \text { versus } c\end{array}$}} & $<0.005$ & $<0.005$ & $n s^{3}$ & $<0.02$ & $<0.01$ & $\mathrm{~ns}$ \\
\hline & & 0.05 & $\mathrm{~ns}$ & ns & $\mathrm{ns}$ & ns & ns \\
\hline & & $\mathrm{ns}$ & ns & $\mathrm{ns}$ & $<0.01$ & $<0.005$ & ns \\
\hline
\end{tabular}

${ }^{1} \mathrm{FFDS}=$ fat-free dry solids.

${ }^{2} \mathrm{NCP}=$ noncollagenous protein.

${ }^{3} \mathrm{~ns}=$ not significant. 
WATERLow and Mendes [38] found that in patients with kwashiorkor the protein/DNA ratio was reduced in musclc, and with rehabilitation a higher ratio was obtained; but it was not clear as to whether normal levels were ever reached. This study, and the inspection of the individual cell mass, leaves little doubt that the metabolically active protein is grossly reduced in marasmus.

In transverse sections of sartorius muscle taken from patients with kwashiorkor, MONTGOMERY [28] found extreme reduction in the cross-sectional area for age and reduction in the area occupied by muscle bundles relative to the total area. Extreme reduction in the individual muscle fibers relative to normal with crowding of the subsarcolemmal nuclei was also reported.

The concentration of $\mathrm{Mg}$ was reduced in muscle before and after rehabilitation. This is in contrast to the findings of MONTGOMERY [27]. He found a restoration of normal values following rehabilitation, while Caddell and Goddard [4] showed, in four malnourished infants, that no increase occurred in the $\mathrm{Mg}$ concentration of muscle 2-3 weeks following treatment. Balance studies [24] indicate that the uptake of $\mathrm{Mg}$ and $\mathrm{K}$ is significant during rehabilitation.

The zinc content of the muscle was reduced in our patients. This finding may indicate a reduction in protein synthesis [34] and of RNA metabolism $[9,12]$ rather than a zinc-deficiency syndrome.

The findings in the muscle of the infant with marasmus, with respect to content of protein, RNA, $\mathrm{Mg}$, and $\mathrm{Zn}$ expressed per unit DNA, support the contention that protein synthesis was compromised. After rehabilitation normal levels were not attained, suggesting that recovery was not complete.

After rehabilitation, the mean value for the chloride space in the muscle of the malnourished infants was only $106 \pm 28 \mathrm{ml} / 100 \mathrm{~g}$ of fat-free dry solid (FFDS), which was low if compared with data from normal infants $(134 \pm 24 \mathrm{ml} / 100 \mathrm{~g} ; P<0.02)$. Similarly, the water per $100 \mathrm{~g}$ FFDS was only $324 \pm 40 \mathrm{ml} / 100 \mathrm{~g}$, which can be compared with a normal value of $372 \pm$ $20 \mathrm{ml} / 100 \mathrm{~g}(P<0.005)$. Thus, normality had not been reached with respect to hydration of the intra- or extracellular phase of muscle.

The demonstration that intracellular water holds a normal relation to creatinine excretion in marasmus suggests that the latter is a valid index of muscle mass. It has been shown [35] that measurements of muscle mass by anthropometric and radiological techniques yield data that correlate with creatinine excretion during the period of marasmus and rehabilitation [1, 30]. AllEYNe [1] raised the question whether during the period of early rehabilitation catabolism of muscle protein was reduced due to rapid growth or whether smaller amounts of creatinine were excreted relative to muscle mass. His arguments can be explained by the fact that muscle mass is proportionally less in infants than in adults $[17,36]$. In the present study, creatinine excretion was measured early in therapy and then 4-9 months later when recovery was well advanced for seven patients.

The number of cells per gram of muscle was double that expected for body length, attesting to the fact that most of the reduction of muscle mass was due to loss of cell size. The calculation of the total number of nuclei in the musculature (muscle mass $\times$ cell number per gram) may not be justifiable in the initial phase, since the first muscle sample might not be representative of the total muscle mass under grossly abnormal circumstances. MONTGOMERY [28] has drawn attention to crowding of muscle nuclei with some increase of fibrocytes under these circumstances. Further work is needed to clarify the situation, but the implication from this study is that in human marasmus, cell size is affected much more than cell number.

The accelerated weight gain seen during recovery from protein deficiency may be closely related to increments in cell size. Patient M5, for example, showed the greatest spurt in cell size and the greatest weight gain. In circumstances where cell number is reduced, such as in patients with congenital heart disease [11], catchup growth is less dramatic, since cell multiplication is time dependent.

It has been suggested that disproportional changes in cell size relative to number of nuclei in muscle occurs in situations where stimulation by either growth hormone or insulin predominate [12]. Growth hormone activity is related to cell replication, while insulin is associated with cytoplasmic growth [10]. In the concurrent study of malnourished infants [16], it was found that some patients initially presented with hyperglycemia, and the intravenous infusion of arginine produced a poor insulin response. Others have demonstrated similar findings $[2,19]$. Protein intake may modify insulin production, or release, or both, which in turn could influence cell size. Indeed, the question arises as to whether supplementary amounts of insulin would enhance the recovery process. Insulin injection into hypophysectomized rats will augment protein accretion in the liver and cause increments in muscle cell size in the intact rat [18] and greater ribosomal activity [41].

Growth hormone levels in serum are either normal or high $[16,32,33]$ in malnutrition; the significance of this is not understood.

Information concerning the composition of adipose tissue of normal and malnourished infants is meager. BAKER [3] estimated that one-third of the body weight at birth is adipose tissue and that by 4 months of age the adipose tissue has increased to one-half the body weight. He found, in infants $6-10$ months of age, that 
water comprised $27 \%$ and fat $69 \%$ of subcutaneous adipose tissue. With advancing age, water concentration decreased and fat concentration increased. The trend toward an increase in water and a decrease in fat in the adipose tissue in marasmus suggests an immature state. It is known that adipose tissue fat is reduced in marasmus and that a redistribution of fat occurs throughout the body [20].

After rehabilitation, marasmic infants frequently gain fat and muscle and lose water $[1,35]$. It is clear from the present data that there was a significant reduction in the concentration of water and collagen in the adipose tissue with rehabilitation, and a gain in fat concentration. Of interest was the finding that the noncollagen protein per gram of tissue did not differ in normal, marasmic, and rehabilitated infants. Since the noncollagen protein must be present mainly in the adipocyte, one might suspect that less change occurred with respect to the number of adipocytes per gram during malnutrition and rehabilitation, while changes in fat cell size were more remarkable.

\section{Summary}

Nine malnourished Peruvian infants, three with kwashiorkor and six with marasmus, were studied before and after 4-9 months of treatment. Seven of the nine reached expected weight for height but none reached expected height for age, and biochemical evidence did not indicate restoration of normality.

Muscle tissue was analyzed for DNA, RNA, protein, collagen, $\mathrm{Mg}, \mathrm{Zn}, \mathrm{Cl}$, and fat. Creatinine excretion was used as an index of muscle mass. The validity of this procedure is discussed. Adipose tissue samples were analyzed for water, fat, collagen, and total protein.

The investigations indicated that protein synthesis in muscle was compromised during marasmus, and loss of cell size accounted for most of the loss of muscle mass. The infants below 0.9 years initially showed the greatest departure. Growth of muscle and fat took place with rehabilitation, but normal levels of protein, RNA, and $\mathrm{Mg}$, in relation to DNA, were not attained.

Studies of adipose tissue indicated levels of fat and water compatible with those of more immature infants.

\section{References and Notes}

1. Alleyne, G.A.O.: Studies on total body potassium in infantile malnutrition: The relation to body fluid spaces and urinary creatinine. Clin. Sci. 34: 199 (1968).

2. Baig, H.A. and Edozien, J.G.: Carbohydrate metabolism in kwashiorkor. Lancet $i i: 662$ (1965).
3. BAKER, G.L.: Human adipose tissue composition and age. Amer. J. clin. Nutr. 22: 829 (1969).

4. Caddell, J.L. and Goddard, D.R.: Studies in protein-calorie malnutrition: I. Chemical evidence for magnesium deficiency. New Engl.J. Med. 276: 533 (1967).

5. CHeEk, D.B.: Total body chloride of children in potassium deficiency and under circumstances of poor nutrition. Pediatrics 14: 193 (1954).

6. CHEEK, D.B.: Extracellular volume: its structure and measurement and the influence of age and disease. J. Pediat. 58: 103 (1961).

7. Cheek, D.B.: Human growth, p.337, 352, 663 (Lea \& Febiger, Philadelphia 1968).

8. Cheek, D.B. and Cooke, R.E.: Growth and growth retardation. Ann. Rev.Med. 15: 357 (1964).

9. Cheek, D.B. and Graystone, J.E.: Ghanges in liver enzymes (GOT and GDH) and metals ( $\mathrm{Zn}$, $\mathrm{Mn}$, and $\mathrm{Mg}$ ) in rats during endocrine imbalance and during calorie restriction. Pediat.Res. 3: 433 (1969).

10. Cheek, D.B. and Graystone, J.E.: The action of insulin, growth hormone, and epinephrine on cell growth in liver, muscle, and brain of the hypophysectomized rat. Pediat. Res. 3: 77 (1969).

11. Gheek, D.B.; Graystone, J. E. and Mehrizi, A.: The importance of muscle cell number in children with congenital heart disease: Bull.Johns Hopk. Hosp. 118: 140 (1966).

12. Greek, D.B. and Hill, D.E.: Muscle and liver cell growth: Role of hormone and nutritional factors, calories, protein, and zinc. Fed. Proc. (in press).

13. Gheek, D.B.; Powell, G.K. and Scott, R.E.: Growth of muscle cells (size and number) and liver DNA in rats and Snell-Smith mice with insufficient pituitary, thyroid, or testicular function. Bull. Johns Hopk. Hosp. 117: 306 (1965).

14. Elliotr, D. A. and Cheek, D. B. : Muscle and liver cell growth in rats with hypoxia and reduced nutrition; in: D. B. CHeEK: Human growth, chapt. 23, p. 326 (Lea \& Febiger, Philadelphia 1968).

15. Garrow, J. S.: Total body potassium in kwashiorkor and marasmus. Lancet $i i: 455$ (1965).

16. Graham, G.G.; Cordano, A.; Blizzard, R.M. and CHeEK, D. B.: Infantile malnutrition: Changes in body composition during rehabilitation. Pediat. Res. 3: 579 (1969).

17. Graystone, J.E.: Creatinine excretion during growth; in: D. B. CHEEK: Human growth, chapt. 12, p. 182 (Lea \& Febiger, Philadelphia 1968).

18. Graystone, J.E. and Cheek, D.B.: The effects of reduced calorie intake and increased insulininduced caloric intake on the cell growth of muscle, liver, and cerebrum and on skeletal collagen in the postweanling rat. Pediat. Res. 3: 66 (1969). 
19. Hadden, D.R. and Beif, M.D.: Glucose, free fatty acid, and insulin interrelations in kwashiorkor and marasmus. Lancet $i i: 589$ (1967).

20. Halliday, D.: Chemical composition of the whole body and individual tissues of two Jamaican children whose death resulted primarily from malnutrition. Clin. Sci. 33: 365 (1967).

21. HARE, R. S.: Endogenous creatinine in serum and urine. Proc. Soc. exp. Biol., N.Y. 74: 148 (1950).

22. Hill, D.E.; Holt, A.B.; PARra, A. and Gheer, D. B.: The influence of protein or calorie deficiency on the body composition and cellular growth of muscle and liver in weanling rats (unpublished data).

23. Kerpel-Fronius, E. and Kovach, I.: Volume of extracellular body fluids in malnutrition. Pediatrics 2: 21 (1948).

24. Linder, G.C.; Hansen, J.D.L. and Kavabus, C.D.: Metabolism of magnesium and other inorganic cations and of nitrogen in acute kwashiorkor. Pediatrics 31: 552 (1963).

25. Mellits, E.D.: Statistical methods; in: D.B. Cheek: Human growth, chapt.2, p.22 (Lea \& Febiger, Philadelphia 1968).

26. Mendes, G.B. and Waterlow, J.C.: The effect of a low protein diet and of refeeding, on the composition of liver and muscle in the weanling rat. Brit.J. Nutr. 12: 74 (1958).

27. Montgomery, R.D.: Magnesium metabolism in infantile protein malnutrition. Lancet $i i: ~ 74$ (1960).

28. Montgomery, R. D. : Muscle morphology in infantile protein malnutrition.J. clin. Path.15: 511 (1962).

29. Nichols, B.L.; Alleyne, G.A.O.; Hazlewood, G.F. and WATERLOW, J. C.: The relations between depletion of total body potassium and depletion of muscle potassium in infants with malnutrition. Fed.Proc. 26: 304 (1967).

30. Picou, D.; Allexne, G.A.O. and Seakins, A.: Hydroxyproline and creatinine excretion in infantile protein malnutrition. Clin. Sci. 29: 517 (1965).

31. Picou, D.; Halliday, D. and Garrow, J.S.: Total body protein, collagen and non-collagen protein in infantile protein malnutrition. Clin. Sci. 30: 345 (1966).

32. Pimstone, B.L.; Barbezat, G.; Hansen, J.D.L. and Murray, P.: Growth hormone and protein calorie malnutrition. Lancet ii: 1333 (1967).
33. Pimstone, B.L.; Wrttmann, W.; Hansen, J.D.L. and Murray, P.: Growth hormone and kwashiorkor. Lancet ii: 779 (1966).

34. Prasad, A.S.; Oberleas, D.; Wolf, P. and Horwitz, J.P.: Studies on zinc deficiency: Changes in trace elements and enzyme activities in tissues of zinc-deficient rats. J. clin. Invest. 46: 549 (1967).

35. Standard, K.L.; Wills, V.G. and Waterlow, J.C.: Indirect indicators of muscle mass in malnourished infants. Amer.J.clin. Nutr. 7: 271 (1959).

36. Stearns, G.; Newman, K.J.; MaKinley, J.B. and JEans, P.C.: The protein requirements of children from one to ten years of age. Ann. N.Y. Acad. Sci. 69: 855 (1958).

37. Talbert, J. L. and Haller, J. A., Jr.: Tissue analysis: Part I. Muscle biopsy technique in infants and children; in: D.B. CHeEK: Human growth, p. 649 (Lea \& Febiger, Philadelphia 1968).

38. Waterlow, J. C. and Mendes, C. B.: Composition of muscle in malnourished human infants. Nature 180: 1361 (1967).

39. Winick, M. and Noble, A.: Cellular response in rats during malnutrition at various ages. J.Nutr. 89: 300 (1966).

40. Young, V.R. and Alexis, S. D.: In vitro activity of ribosomes and RNA content of skeletal muscle in young rats fed adequate or low protein. J. Nutr. 96: 255 (1968).

41. Young, V.R.; Chen, S.C. and Macdonald, J.: The sedimentation of ratskeletal-muscle ribosomes: Effect of hydrocortisone, insulin and diet. Biochem. J. 106: 913 (1968).

42. All procedures have been performed in accordance with the provisions set forth in the Declaration of Helsinki.

43. Donald E.Hull, Research Fellow, recipient of R. Samuel Malaughlin Fellowship, Toronto, Canada.

44. Supported by Public Health Service Research Grants nos. HD 00126-06 and 09980 from the National Institute of Child Health and Human Development and the National Institute of Arthritis and Metabolic Diseases, respectively.

45. Requests for reprints should be addressed to: D.B. Gheek, M.D., The Johns Hopkins Hospital, 601 N. Broadway, Baltimore, MD 21205 (USA). 46. Accepted for publication October 3, 1969. 